\section{Calprotectin is not independent from baseline erosion in predicting radiological progression in early rheumatoid arthritis. Comment on 'Calprotectin as a marker of inflammation in patients with early rheumatoid arthritis' by Jonsson et al}

We have read with great interest the article by Jonsson et al that was recently published online in $A R D,{ }^{1}$ which suggested that calprotectin, also known as S100A8/S100A9 heterodimer, was associated with radiographic progression in early rheumatoid arthritis (RA). Calprotectin correlates significantly with inflammatory markers and disease activity score. ${ }^{2}$ Besides correlations between baseline calprotectin levels, Clinical Disease Activity Index and ultrasonography power Doppler, the authors showed that baseline calprotectin levels correlated with van der Heijde modified Sharp score (SHS) progression (defined as an increase $\geq 1$ unit/year from 0 to 24 months), independently of age, gender, Clinical Disease Activity Index, erythrocyte sedimentation rate (ESR), $\mathrm{C}$ reactive protein (CRP) levels and rheumatoid factor positivity. ${ }^{1}$

We analysed the initial serum calprotectin among patients with early RA fulfilling American College of Rheumatology/European League Against Rheumatism 2010 of the French observational cohort Etude et Suivi des POlyarthrites Indifférenciées Récentes (ESPOIR). Calprotectin serum concentrations were assessed according to manufacturer method (Hycult, Frontstraat, Netherlands; standard range from 1.6 to $25 \mathrm{ng} / \mathrm{mL}$ ). Univariate and multivariate risk Cox models with a backward stepwise were constructed for 615 patients with early RA for whom radiological data were available. Outcome measures included in the analysis were gender, CRP, anti-citrullinated peptide antibody (ACPA), Disease Acivity Score, age, smoking status, calprotectin, disease-modifying antirheumatic drugs (DMARDs) treatment and typical initial erosion. The radiological progression was defined as an increase $\geq 5$ of the total SHS score/year.

CRP, ACPA, DMARD treatment and calprotectin were significantly associated with structural evolution in the univariate analysis. When baseline erosion was removed from the multivariate analysis, calprotectin was the only predictor of the structural evolution over 3 years (HR 1.06, 95\% CI $(1.00$ to 1.11$), P=0.045$, table 1$)$. These results confirmed that calprotectin predicts radiological progression in a large cohort of early RA. When the presence of baseline typical erosion was combined in the multivariate Cox model, calprotectin was not an independent predictor of structural evolution anymore (HR 1.03 , 95\% CI (0.97 to 1.10$), \mathrm{P}=0.297$ ).

Calprotectin, which is predominantly expressed by myelomonocytic cells and constitutes $40 \%$ of the polymorphonuclear neutrophil cytosolic proteins, ${ }^{3}$ was identified as a marker of RA in the synovial fluid and in the serum, with serum concentrations differentiating RA from other rheumatic diseases. ${ }^{4}$ Besides their intracellular functions, ${ }^{5}$ calprotectin has been introduced as an important proinflammatory factor mainly secreted by activated neutrophils. A direct role in radiological damage has been suggested because of the activation of matrix metalloproteases by $\mathrm{S} 100$ proteins. $^{6}$

We acknowledge the putative role of new biomarkers, ${ }^{2}$ such as calprotectin, in early RA management. Jonsson et al showed that calprotectin is a better predictor of structural progression than ESR or CRP. In order to know whether calprotectin should be implemented in daily practice, it is critical to determine whether calprotectin is also independent from major predictors of structural evolution in RA, such as ACPA and baseline erosion. ${ }^{7}$ In ESPOIR cohort, calprotectin is no more associated with structural damage when baseline erosion is considered.

\section{Maxime Chevreau, ${ }^{1}$ Marie-Hélène Paclet, ${ }^{2,3}$ Xavier Romand, ${ }^{1,2}$ Jean-Louis Quesada, ${ }^{4,5}$ Olivier Vittecoq ${ }^{6}$ Philippe Dieudé, ${ }^{7}$ Bertrand Toussaint, ${ }^{8}$ Philippe Gaudin, ${ }^{1,2}$ Athan Baillet ${ }^{1,2}$ \\ ${ }^{1}$ Department of Rheumatology, Grenoble Alpes University Hospital, Grenoble, France ${ }^{2} U$ niv Grenoble Alpes, GREPI-UGA EA7408, Grenoble, France \\ ${ }^{3}$ Lab. Biochimie des Enzymes et des Protéines, Centre Hospitalier Universitaire Grenoble Alpes, Grenoble, France \\ ${ }^{4}$ INSERM, Clinical Investigation Center CIC P 1406, Grenoble Alpes University Hospital, Grenoble, France \\ ${ }^{5}$ Scientific Department of the Clinical Research Delegation, Grenoble Alpes University Hospital, Grenoble, France \\ ${ }^{6}$ Department of Rheumatology, Rouen Hospital, Bois-Guillaume, France \\ ${ }^{7}$ Department of Rheumatology, Bichat Hospital, Paris, France \\ ${ }^{8}$ Laboratoire TIMC-IMAG-TheREx, UMR 5525 Centre National de la Recherche Scientifique, Univ Grenoble Alpes, Grenoble, France}

Correspondence to Dr Athan Baillet, Rheumatology, Grenoble Alpes University Hospital, Université Grenoble Alpes, Echirolles 38434 Cedex, France; abaillet@chu-grenoble.fr

Acknowledgements We wish to thank Nathalie Rincheval (CHU Montpellier and EA 2415) who did expert monitoring and data management and all the investigators who recruited and followed the patients (F Berenbaum, Paris-Saint Antoine; MC Boissier, Paris-Bobigny; A Cantagrel, Toulouse; B Combe, Montpellier;

\begin{tabular}{|c|c|c|c|c|c|c|}
\hline$N=615$ & $\begin{array}{l}\text { No radiological } \\
\text { progression, } n=290\end{array}$ & $\begin{array}{l}\text { Radiological } \\
\text { progression, } n=325\end{array}$ & $\begin{array}{l}\text { Univariate analysis } \mathrm{HR} \\
(95 \% \mathrm{Cl})\end{array}$ & $P$ value & $\begin{array}{l}\text { Multivariate } \\
\text { analysis HR }(95 \% \mathrm{Cl})\end{array}$ & $P$ value \\
\hline Female gender (\%) & $79.3 \%(230)$ & $76.9 \%(250)$ & 0.95 (0.73 to 1.23$)$ & 0.696 & - & - \\
\hline CRP (mg/dL) & 7 (4 to 18$)$ & 12 (5 to 28 ) & 1.03 (1 to 1.06$)$ & 0.047 & Not selected & \\
\hline ACPA (IU) & 0 (0 to 256$)$ & 121 (0 to 572 ) & 1.01 (1 to 1.01$)$ & 0.040 & 1.01 (1 to 1.01 ) & 0.093 \\
\hline DAS-28 & $5.2 \pm 1.22$ & $5.3 \pm 1.2$ & $1.07(0.98$ to 1.17$)$ & 0.148 & - & - \\
\hline Age (years) & 48.7 (38 to 56.3 ) & 52.4 (41.1 to 58.4$)$ & 1.01 (1 to 1.02 ) & 0.082 & - & - \\
\hline Current smoking & $48.3 \%(140)$ & $46.8 \%(152)$ & $1.04(0.84$ to 1.29$)$ & 0.732 & - & - \\
\hline DMARDs (\%) & $77.2 \%(224)$ & $86.8 \%(282)$ & 1.50 (1.09 to 2.07$)$ & 0.013 & $1.36(0.99$ to 1.89$)$ & 0.060 \\
\hline Calprotectin $(\mu \mathrm{g} / \mathrm{cL})$ & 3.2 (1.88 to 4.8$)$ & 3.8 (2.3 to 5.3$)$ & 1.06 (1.01 to 1.12$)$ & 0.027 & 1.06 (1 to 1.11$)$ & 0.045 \\
\hline \multicolumn{7}{|c|}{$\begin{array}{l}\text { Univariate and multivariate analyses: Cox model; HR }(95 \% \mathrm{Cl}) \text {. } \\
\text { Percentage (number); mean } \pm \text { SD or median ( } 25 \text { th, } 75 \text { th centiles) where appropriate. } \\
\text { ACPA, anti-citrullinated protein/peptide antibody; } C R P, C \text { reactive protein (mg/dL); DAS- } 28 \text {, DiseaseActivity Score-28; DMARDs, disease-modifying antirheumatic drugs, that is, } \\
\text { methotrexate } \geq 7.5 \mathrm{mg} / \text { week, leflunomide at the visit before radiological evolution or at the last follow-up visit; IU, international unit; Not selected, outcome was excluded from } \\
\text { multivariate Cox model because P value for model entry was }>0.5 \text { or P value for model retention was }>0.10 \text {. Radiological progression was defined as an increase } \geq 5 \text { of the total } \\
\text { SHS score. }\end{array}$} \\
\hline
\end{tabular}


M Dougados, Paris-Cochin; P Fardelone et P Boumier, Amiens; B. Fautrel, Paris-La Pitié; RM Flipo, Lille; Ph Goupille, Tours; F Liote, Paris-Lariboisière; $O$ Vittecoq, Rouen; X Mariette, Paris Bicetre; 0 Meyer et Ph Dieude, Paris Bichat; A Saraux, Brest; Th Schaeverbeke, Bordeaux; I Sibilia, Strasbourg). We thank V Devauchelle and C Lukas for expert X-ray reading and S Martin (Paris Bichat) who did all the central dosages of Creactive protein, IgA rheumatoid factor and IgM rheumatoid factor and anti-citrullinated protein antibodies. The authors thank Ms Sylvie Papacatsis for her contribution to this study.

Contributors MC, M-HP, XR, J-LQ and AB have made substantial contributions to the conception or design of the work, or the acquisition, analysis or interpretation of data. OV, PD, BT and PG have revised the draft critically for important intellectual content and have approved the final version published.

Funding An unrestricted grant from Merck Sharp and Dohme (MSD) was allocated for the first 5 years. Two additional grants from Institut national de la santé et de la recherche médicale (INSERM) were obtained to support part of the biological database. The French Society of Rheumatology, Pfizer, Abbvie and Roche-Chugai also supported the Etude et Suivi des POlyarthrites Indifférenciées Récentes INSERM (ESPOIR) cohort study. This study was funded by the Scientific Department of the Clinical Research Delegation (DRCl), Grenoble Alpes University Hospital.

Competing interests None declared.

Ethics approval The Montpellier ethics committee.

Provenance and peer review Not commissioned; externally peer reviewed.

(c) Article author(s) (or their employer(s) unless otherwise stated in the text of the article) 2018. All rights reserved. No commercial use is permitted unless otherwise expressly granted.

\section{A) Check for updates}

To cite Chevreau M, Paclet M-H, Romand X, et al. Ann Rheum Dis 2018;77: e84.
Received 8 December 2017

Accepted 15 December 2017

Published Online First 10 January 2018

\section{CP Linked}

http://dx.doi.org/10.1136/annrheumdis-2017-212869

Ann Rheum Dis 2018;77: e84. doi:10.1136/annrheumdis-2017-212816

\section{REFERENCES}

1 Jonsson MK, Sundlisæter NP, Nordal HH, et al. Calprotectin as a marker of inflammation in patients with early rheumatoid arthritis. Ann Rheum Dis 2017:76:2031-7.

2 Hammer HB, Fagerhol MK, Wien TN, et al. The soluble biomarker calprotectin (an S100 protein) is associated to ultrasonographic synovitis scores and is sensitive to change in patients with rheumatoid arthritis treated with adalimumab. Arthritis Res Ther 2011;13:R178.

3 Baillet A. [S100A8, S100A9 and S100A12 proteins in rheumatoid arthritis]. Rev Med Interne 2010:31:458-61.

4 Baillet A, Trocmé C, Berthier S, et al. Synovial fluid proteomic fingerprint: S100A8, S100A9 and S100A12 proteins discriminate rheumatoid arthritis from other inflammatory joint diseases. Rheumatology 2010;49:671-82.

5 Berthier S, Nguyen MV, Baillet A, et al. Molecular interface of S100A8 with cytochrome b558 and NADPH oxidase activation. PLoS One 2012:7:e40277.

6 Edgeworth J, Gorman M, Bennett R, et al. Identification of p8,14 as a highly abundant heterodimeric calcium binding protein complex of myeloid cells. J Biol Chem 1991;266:7706-13

7 Baillet A, Gossec L, Paternotte S, et al. Evaluation of serum interleukin-6 level as a surrogate marker of synovial inflammation and as a factor of structural progression in early rheumatoid arthritis: results from a French national multicenter cohort. Arthritis Care Res 2015;67:905-12. 